\title{
Polyfunctional properties of goat colostrum proteins and their use
}

\author{
K. I. Soloshenko, I. V. Lych ${ }^{1}$, I. M. Voloshyna ${ }^{1,2}$, L. V. Shkotova ${ }^{3}$ \\ ${ }^{1}$ National University of Food Technologies \\ 68, Volodymyrska Str., Kyiv, Ukraine, 01601 \\ ${ }^{2}$ Kyiv National University of Technologies and Design \\ 2, Nemirovich-Danchenko Str., Kyiv, Ukraine, 01011 \\ ${ }^{3}$ Institute of Molecular Biology and Genetics, NAS of Ukraine \\ 150, Akademika Zabolotnoho Str., Kyiv, Ukraine, 03143 \\ luda_shkotova@yahoo.com
}

\begin{abstract}
The review presents the composition of goat colostrum, antimicrobial, immunomodulatory and antioxidant properties of biologically active proteins of goat colostrum, as well as the prospects of their use in medicine. Due to the presence of a complex of biologically active proteins such as lactoferrin, lysozyme, lactoperoxidase, immunoglobulins, etc., goat colostrum increases the body's resistance to infectious diseases, strengthens the immune system, has an antioxidant effect and antibacterial activity against a wide range of microorganisms, thereby preventing or delaying chronic diseases associated with the oxidative stress. Additionally, goat colostrum bioactive proteins show antitumor activity, antiatherogenic properties, the ability to lower the blood pressure and efficiency in the treatment of rheumatoid arthritis.
\end{abstract}

Keyword s: goat colostrum, protein complex, antimicrobial activity, immunomodulatory properties, antioxidant effect, therapeutic use.

\section{Introduction}

Recently, the research of properties of goat colostrum has become more popular, because it is the primary milk released by mammals during parturition and the first few days after birth; it contains a large number of biologically active proteins, which might be used for treatment of various diseases. Additionally, goat colostrum is very close to breast milk, so its use in infant formula is quite promising. Colostrum differs from milk in high content of proteins, vitamins, minerals, lactoferrin, lysozyme, antimicrobial peptides, immunoglobulins [1]. Besides, the nutritional properties of goat colostrum and its lower allergenicity, compared to bovine colostrum, cause an interest to goat milk and colostrum as functional products.

(C) 2020 K. I. Soloshenko et al.; Published by the Institute of Molecular Biology and Genetics, NAS of Ukraine on behalf of Biopolymers and Cell. This is an Open Access article distributed under the terms of the Creative Commons Attribution License (http://creativecommons.org/licenses/by/4.0/), which permits unrestricted reuse, distribution, and reproduction in any medium, provided the original work is properly cited 


\section{The composition of goat colostrum}

It has been shown that goat colostrum, compared to bovine colostrum, is more valuable, because it is better digested and contains $33 \%$ less protein $\alpha$ s1-casein, which can form solid clots in the stomach causing digestive problems in infants. Compared to bovine colostrum, goat colostrum contains more free amino acids, magnesium, selenium and glutathione peroxidase, which means that goat colostrum has better antioxidant properties [2].

Another advantage of goat colostrum is that its composition is very similar to human milk. Goat colostrum contains the same amount of vitamins as human milk, but the content of folic acid, vitamin C and inositol is lower [3]. The amino acid composition of goat colostrum is also similar to human milk [4].

Goat colostrum contains a high amount of proteins. The protein concentration in colostrum is more than 2 times higher than in milk [5]. The content of the main components of colostrum varies depending on the period after the birth (Table 1) [6,7].

Therefore, the concentrations of the major colostrum components vary significantly during the postpartum period. The highest concentration of proteins, including lactoferrin and immunoglobulins, is observed immedi- ately after lambing and on the first day after lambing. However, there is a sharp decline in these components on the second day after lambing. On the contrary, the lactose level increases during the lactation period. These data indicate that the earliest colostrum (1st, 2 nd days) is the best source of bioactive peptides $[6,7]$.

Casein is the major protein fraction in goat colostrum, its content amounts to about $80 \%$ of the total protein [3]. It includes $70.2 \%$ of $\beta$-casein, $29.8 \%$ of $\alpha$-casein, $\kappa$-casein is also present. The molecular weight of casein fractions ranges from 19 to $25 \mathrm{kDa}$ [8].

Goat colostrum contains two types of $\beta$-casein: A1 and A2. These types differ in the sequence of amino acids. Type A1 contains histidine at the 67 position of the amino acid sequence of $\beta$-casein, whereas type A2 has proline at this position. The $\beta$-casein A2 fraction has many essential amino acids, especially branched-chain amino acids, such as leucine, valine and isoleucine. The physicochemical properties of the $\beta$-casein A2 fraction, including the solubility and viscosity of the protein, are similar to cow's milk $\beta$-casein, which is widely used as a protein source in various foods. Therefore, the $\beta$-casein A2 fraction of goat colostrum can be useful as a nutri-

Table 1. The change of chemical composition of goat colostrum [6, 7]

\begin{tabular}{l|l|l|l|l|l|l|l}
\hline \multirow{2}{*}{$\begin{array}{c}\text { Days } \\
\text { postpartum }\end{array}$} & \multirow{2}{*}{ Proteins, $\%$} & \multirow{2}{*}{ Fats, $\%$} & \multirow{2}{*}{ Lactose, $\%$} & \multirow{2}{*}{ Lactoferrin, $\mathrm{mg} / \mathrm{l}$} & \multicolumn{3}{|c}{ Immunoglobulins } \\
\cline { 7 - 9 } & & & & & IgG, $\mathrm{mg} / \mathrm{ml}$ & IgA, $\mathrm{mg} / \mathrm{ml}$ & IgM, $\mathrm{mg} / \mathrm{ml}$ \\
\hline 0 & 10.47 & 7.7 & 2.44 & 207.39 & 32.99 & 0.86 & 3.84 \\
\hline 1 & 6.84 & 6.86 & 3.53 & 204.83 & 20.13 & 0.4 & 1.2 \\
\hline 2 & 5.73 & 6.26 & 4.15 & 66.23 & 8.23 & 0.24 & 0.7 \\
\hline 4 & 5.64 & 6.15 & 3.98 & 58.58 & 6.05 & 0.19 & 0.59 \\
\hline 5 & 5.2 & 6.43 & 4.2 & 47.45 & 2.16 & 0.17 & 0.38 \\
\hline
\end{tabular}


ent with good digestibility and hypoallergenic properties for infants and people with metabolic disorders [9].

There are two main groups of whey proteins - lactoalbumins and lactoglobulins. The feature of globulins is that they fold during heating whereas albumins precipitate. $\beta$-lactoglobulin is the major whey protein in goat colostrum (50\% of total whey protein) followed by caseinomacropeptide $(21.75 \%)$, $\alpha$-lactalbumin (11.96\%), immunoglobulin G $(9.49 \%)$ and seroalbumin (4.79\%) [10].

$\beta$-Lactoglobulin has antitumor functions and can be involved in the regulation of enzyme activity, it is also able to bind hydrophobic molecules such as retinol, fatty acids, steroids, etc. Goat colostrum lactoglobulin is a lipocalin protein that has a sequence very similar to bovine lactoglobulin. There are two crystal forms of lactoglobulin - trigonal form and orthorhombic form with a unique molecular structure. Lactoglobulin molecules have an EF-loop in a closed conformation in the trigonal structure, whereas in the orthorhombic structure they have symmetric and asymmetric dimers [12].

$\beta$-lactoalbumin promotes the growth of bifidobacteria, as well as the absorption of calcium and zinc [11]. The molecular weight of $\alpha$-lactoalbumin is $16.2 \mathrm{kDa}$ [13]. Its main function is the interaction with $\beta-1,4$-galactosyltransferase-1 with the formation of the lactosynthase complex responsible for lactose synthesis [14].

The main antimicrobial protein in goat colostrum is lactoferrin. The molecular weight of lactoferrin is approximately $80 \mathrm{kDa}$ [15].

Lactoferrin is an iron-binding glycoprotein, which possesses various biological and protec- tive functions, including iron metabolism, cell proliferation, antibacterial, antifungal, antiviral, antioxidant, immunomodulatory and anticancer activities. Lactoferrin has antibacterial activity against both gram-negative and grampositive bacteria. The antibacterial activity is associated with the lactoferrin ability to disrupt the membrane of the microorganisms and to bind iron in their biological fluids, which are the nutrients essential for bacteria to grow [16].

The functions of lactoferrin and its biological activity are modulated by polypeptide chains and glycosylation of lactoferrin. There are three types of N-glycans: high-mannose, hybrid-sialylated and hybrid-fucosylated. Human and goat lactoferrins contain $37 \%$ of sialylated and $34 \%$ of fucosylated N-glycan sequences. Goat colostrum lactoferrin contains $15 \mathrm{~N}$-glycans, which are also present in human milk. So there is a significant degree of homology for lactoferrin $N$-glycans between human and goat colostrum [17].

$1-4 \%$ of milk proteins are the proteins of the fat globule membrane. 423 fat globule proteins were found in goat colostrum. The content of these proteins in colostrum is higher than in milk. The functions of these proteins are nucleotide binding, cell surface binding and regulation of structural molecules activity.

Among fat globule proteins there are those responsible for inflammatory reactions. For example, complement $\mathrm{C} 3$ plays a central role in the acute phase inflammatory reactions. Its deficiency causes the susceptibility to bacterial infections. The lipopolysaccharide-binding protein binds bacterial lipopolysaccharides to initiate an immune response [18].

The unique biologically active peptides such as dipeptidyl peptidase, transcription fac- 
tor A, interleukin 12 subunit, oligodendrocyte transcription factor 2 were also identified in goat colostrum. The transcription factor $\mathrm{A}$, a major activator of mitochondrial transcription, is involved in mitochondrial genome replication and repair $[19,20]$. The interleukin 12 subunit acts on T-killer cells. The oligodendrocyte transcription factor 2 binds a DNA helix, acts in central nervous system as an anti-neurigenic and a neurigenic factor at different stages of development. It determines the motor neuron and oligodendrocyte differentiation and has a potent role in the sustaining of replication. Its use is possible in such diseases as brain tumor and Down syndrome. Dipeptidyl peptidase plays an important role in the processing of granzymes, neutral serine proteases, which are expressed in granules of activated cytotoxic lymphocytes and cause their apoptosis $[19,21]$.

Immunoglobulins Ig A, Ig M, Ig G are important components of goat colostrum, because they provide passive immunity for newborn goats [5].

IgA protects the intestinal membrane as well as the mucous membranes of the throat, lungs and intestines of the infant from Escherichia coli.

IgM is immunoglobulin first formed in response to antigen, it is highly efficient in enhancement of immunity through complement fixation, agglutination and opsonic activity [5].

IgG known as Ig G1 and Ig G2 is very important for the formation of antibacterial immunity [22]. The average refractometer value of IgG in goat colostrum is $6.78 \mathrm{mg} / \mathrm{ml} \mathrm{[23].}$

Consequently, goat colostrum is rich in biologically active proteins that are involved in protecting the organism against infection, in maintaining the immune system. Additionally, given that goat colostrum is most closely related to breast milk, its use for infant feeding is quite promising.

\section{Antimicrobial properties of goat colostrum proteins}

Goat colostrum contains bioactive peptides that have the antibacterial activity against a wide spectrum of microorganisms. The antimicrobial activity of colostrum proteins is mainly associated with the inhibition of cell wall synthesis, through prevention of its final step - the transpeptidation reaction [24].

Is it known that lactoferrin, lysozyme, lactoperoxidase and immunoglobulins, which are present in goat colostrums, have antimicrobial properties and form a natural system of human protection against a large number of pathogenic microorganisms [25].

Antimicrobial peptides from goat milk are the peptide fragments with a molecular weight less than $10 \mathrm{kDa}$. Most amino acid residues of these peptides are hydrophobic. The amino acid sequence of antimicrobial peptides usually consists of 2-20 amino acids, the peptides of this size are able to pass through the membranes of bacteria, therefore, have a higher antimicrobial activity.

Most of the goat milk antimicrobial peptides are cationic proteins, thereby forming $\alpha$-helices and $\beta$-sheet structures that can selectively interact with anionic bacterial membranes and alter their permeability, causing bacterial death [26].

There is an evidence in the literature that goat colostrum contains antimicrobial and antioxidant compounds that inhibit the growth of Escherichia coli, Bacillus cereus, Listeria 
monocytogenes and Staphylococcus aureus [27]. Among these compounds there is a casein protein $\alpha-\mathrm{S} 2$ which has an anti-inflammatory effect; casein $\alpha$-S2 has antimicrobial activity against pathogenic gram-positive (L. monocytogenes, $S$. aureus and B. cereus) and gramnegative (E. coli, Salmonella typhi and Shigella flexneri) bacteria [22]. Lactoperoxidase present in goat colostrum is effective against bacteria that cause cholera (Vibrio cholerae), typhus (S. typhi), pneumonia (Klebsiella pneumoniae), dysentery (Shigella dysenteriae) and food poisoning (S. aureus) [28]. The bactericidal activity of lactoperoxidase is associated with the oxidation of thiocyanate in the presence of hydrogen peroxide [16].

Additionally, goat colostrum glycomacropeptide is able to attach to enterotoxins of various bacteria [25].

Hydrolysis of goat colostrum proteins increases antimicrobial activity [24-26, 29]. Scientists have found that colostrum hydrolyzed with trypsin, ficin, or their mixture, exhibits the antimicrobial activity against E. coli and B. cereus, which is approximately $29 \%$ higher than that of non-hydrolyzed colostrum. Colostrum proteins hydrolyzed with trypsin shows maximal inhibition against gram-positive and gram-negative bacteria [26].

Bioactive peptides of goat colostrum hydrolyzed by human gastrointestinal enzymes show strong antibacterial activity against $E$. coli K12, B. cereus RT INF01, L. monocytogenes, lower activity against $S$. aureus ATCC 25923. Among antimicrobial peptides, $\beta$-lactoglobulin and $\beta$-casein have been identified [25].

It has been found that goat whey protein hydrolysates obtained using Bacillus licheni- formis alcalase exhibit significantly higher antibacterial activity than non-hydrolyzed goat milk. The antimicrobial activity of hydrolyzed proteins increased compared to non-hydrolyzed proteins, which is evidenced by the growth inhibition zones for different cultures [24]. For example, the growth inhibition zone for $S$. typhimurium in the presence of hydrolyzed goat milk is $22.3 \mathrm{~mm}$ whereas it is 4.53 $\mathrm{mm}$ in the presence of unhydrolyzed milk proteins. The inhibition zone for $S$. aureus is $15 \mathrm{~mm}$ and $7.73 \mathrm{~mm}$ respectively. It is also known [29] that the growth inhibition zones of $E$. coli and B. cereus in the presence of hydrolyzed goat colostrum are 18 and $13.3 \mathrm{~mm}$ respectively, whereas non-hydrolyzed colostrum does not inhibit the growth of these cultures at all [24, 29].

It was found that two antimicrobial peptides obtained by hydrolysis of $\beta$-lactoglobulin have a slight positive net charge at $\mathrm{pH} 7$ and therefore might be able to interact with the cell wall of bacteria. Additionally, these proteins contain the sequence Val-Ala-Gly-Thr-Trp-Tyr, which is characterized by antimicrobial activity. On the other hand, $\alpha$-lactoglobulin peptides have a small negative net charge at $\mathrm{pH} 7$ and therefore are characterized by low antibacterial activity [24].

The antibacterial activity of goat colostrum whey proteins was also evaluated by minimal inhibitory concentration (MIC) ranging from 125 to $500 \mu \mathrm{g} / \mathrm{ml}$ against gram-positive (S. aureus ATCC 25619) and gram-negative (Pseudomonas aeruginosa ATCC 8027, P. aeruginosa ATCC 23243, E. coli 105, E. coli 101) strains. Antibacterial activity was not observed for strains Bacillus subtilis CCT 0516, E. coli ATCC 2536, E. coli ATCC 10536, E. coli 104, 
E. coli 108, E. coli 110 and S. aureus ATCC 6538 with the MIC $>1000 \mu \mathrm{g} / \mathrm{ml}[16]$.

The MIC of peptides obtained by hydrolysis of goat colostrum proteins was $383 \pm 8 \mu \mathrm{g} / \mathrm{ml}$ against $E$. coli and $492 \pm 10 \mu \mathrm{g} / \mathrm{ml}$ against B. cereus [26].

However, on the other hand, goat colostrum does not inhibit normal intestinal microflora. It was found that goat colostrum proteins do not inhibit the growth of Lactobacillus rhamnosus GG. Furthermore, lactoferrin of goat colostrum can increase the growth of probiotic strains of Lactobacillus [25].

Lysozyme of goat colostrum is able to restore the composition of the normal gut microbiota. It was investigated that consumption of goat milk enriched with lysozyme resulted in the enrichment of Bifidobacteriacea and Lactobacillacea bacterium in the gastrointestinal tract. These changes were accompanied by the reduction of Clostridia spp., Streptococcaceae, Mycobacteriaceae and Campylobacterales strains [30].

Besides, the non-digestible oligosaccharides present in goat colostrum can promote the growth of beneficial gut bacteria and prevent the growth of pathogenic bacteria [31].

Moreover, lactic acid bacteria, which are present in goat milk and colostrum, are able to produce bacteriocins that inhibit the growth of a wide range of pathogenic and conditionally pathogenic microorganisms. For example, the strain Lactobacillus sakei GM3 produces bacteriocins active against pathogens such as P. aeruginosa, K. pneumonia, Salmonella, L. monocytogenes [32]. Strains L. rhamnosus and L. plantarum isolated from goat milk produce bacteriocins that inhibit the growth of S. aureus [33].
In conclusion, the whey and casein proteins of goat colostrum as well as the peptides obtained by hydrolysis of these proteins have antimicrobial properties against gram-positive and gram-negative bacteria. However, the hydrolysis of proteins increases antimicrobial activity. Therefore, these bioactive peptides of goat colostrum can be used to combat infectious pathogens.

\section{Immunomodulatory properties of biologically active fragments of goat colostrum}

Bioactive fragments of goat colostrum play a leading role in the strengthening of immune system. The immunomodulatory effect of goat colostrum is ensured by releasing nitric oxide (NO) and cytokines, as well as by inhibiting the formation of pro-inflammatory markers $[22,30]$.

Goat colostrum proteins are able to activate NO release from blood cells and activate the cytokine synthesis (IL-10, TNF- $\alpha$ and IL-6). It is known that the release of NO provides a cardioprotective effect, exhibits antibacterial activity and thus prevents infections. TNF- $\alpha$ and IL-10 are anti-inflammatory cytokines and IL-6 is a growth factor for B cells [22].

Goat colostrum whey proteins have an antiinflammatory effect. They are able to inhibit signaling pathways and reduce the expression of genes of various proinflammatory markers, such as IL-1 $\beta$, IL-6, IL-17, TNF- $\alpha$ (tumor necrosis factor), iNOS (inducible nitric oxide synthase), MMP-9 (matrix metalloproteinase), ICAM (intercellular adhesion molecule). Thus, these proteins could be applied for the treatment of inflammatory infections of the gastrointestinal tract [30]. 
Additionally, goat milk and colostrum contain sialic acids, the functions of which are the activation of immune system, the brain development and protection against pathogens. Sialic acids are usually involved in the processes of cellular interaction and protection of macromolecules and cells from enzymatic and immunological attacks. Goat milk contains sialic acids (such as N-glycolylneuraminic acid NeuGc and $\mathrm{N}$-acetylneuraminic acid NeuAc) in high concentrations, decreasing during lactation [31].

Therefore, due to the presence of immunomodulatory compounds in goat colostrum, its use in the activation of immune defense and treatment of inflammatory infections seems promising.

\section{Antioxidant properties of goat colostrum bioactive peptides}

The antioxidant peptides present in goat colostrum can prevent or delay chronic diseases associated with oxidative stress.

In living organisms, the reactive oxygen species, or free radicals (such as superoxide anion radical, nitric oxide) are the products of normal cellular metabolism. At low to moderate concentrations, free radicals function in physiological cell processes, but at high concentrations they cause adverse changes of cellular components such as lipids, proteins and DNA. Therefore, during excessive oxidative stress, the degradation of lipid bilayer plasma membrane by peroxidation may cause cell death [32]. Reactive oxygen species can cause various diseases, such as hypertension and stroke [27].

Goat colostrum antioxidant compounds can inhibit oxidation via various mechanisms, such as the capturing of reactive oxygen species and other free radicals or the chelation of metal ions, for example iron. The antioxidant activity is exerted by lactoferrin, $\beta$-lactoglobulin and serum albumin. The antioxidant action of $\beta$-lactoglobulin and serum albumin might be due to the presence of cysteine, which is a precursor for the synthesis of glutathione, a well-recognized antioxidant, and the presence of a thiol group in $\beta$-lactoglobulin [16]. The whey and casein protein hydrolysates exhibit the activity against superoxide anion [33]. The antioxidant properties of goat colostrum casein hydrolysates are associated with the presence of peptides rich in amino acids such as histidine, lysine, proline and tyrosine [34].

Antioxidant activity, determined by the 2-diphenyl-1-picrylhydrazyl radical scavenging assay, is higher in late lactation goat milk. It is supposed that the latter could be a source of bioactive components to prevent oxidative stress and aging [35].

Compared to caseins of goat milk, the free radical scavenging ability and ferrous ion chelating ability of casein hydrolysates are significantly higher. The inhibition effect of lipid peroxidation with goat milk casein hydrolysates is much stronger than that of tert-butylhydroquinone and phytogermine and a little weaker compared to ascorbic acid. The antioxidant activity of hydrolysates could be explained by a high antioxidant activity of oligopeptides, especially of 5 novel oligopeptides: Val-Tyr-Pro-Phe, Phe-Gly-Gly-Met-AlaHis, Phe-Pro-Tyr-Cys-Ala-Pro, Tyr-Val-ProGlu-Pro-Phe, and Tyr-Pro-Pro-Tyr-Glu-ThrTyr, which were first observed in goat milk hydrolysates. The antioxidant activity of these hydrolysates increased 3.59 to 380 times compared to non-hydrolyzed milk [36]. 
The goat milk peptides obtained using hydrolysis with subtilisin or trypsin exhibited a high iron chelation capacity and inhibition of formation of secondary lipid oxidation products. The goat milk protein hydrolysates also demonstrated the ability to inhibit the formation of secondary oxidation products in phosphatidylcholine liposomes.

Tyrosine plays a fundamental role in the radical scavenging capacity of these peptides. Peptides with large amount of phenylalanine exhibit the ability to inhibit the formation of secondary lipid oxidation products. In fact, phenylalanine is present in $50 \%$ of the identified antioxidant peptides. The high activity of phenylalanine-containing peptides may be attributed to the ability of phenylalanine to interact with the hydroxyl radical $(\cdot \mathrm{OH})$, which is generated by iron induced oxidation, turning phenylalanine into $p$-, $o$ - or $m$-tyrosine, thus reducing the generation of novel lipid peroxides. Tyrosine in turn can react with lipid radicals inhibiting the formation of secondary lipid oxidation products [37].

Thus, goat milk and colostrum contain peptides with antioxidant activity, so these peptides can be used in biologically active additives, which are the source of natural antioxidants, as well as in food to reduce the oxidation reactions that lead to spoilage.

\section{Anticancer activity of biologically active goat colostrum proteins}

Goat colostrum bioactive peptides can be effective in the prevention of cancer [16, 38-39]. The most important anti-cancer protein is lactoferrin. Its antitumor activity is attributed to the fact that this protein has immunomodulatory potential and ability to activate $\mathrm{T}$ and NK cells.
The activity of lactoferrin was investigated against two cell lines - HeLa (human cervical cancer) cell line and a rat embryo fibroblast (REF) cell line. The inhibition rate increased with the rising of lactoferrin concentration and increasing incubation period. The highest growth inhibition $(64.38 \%)$ was observed on HeLa cell line at the concentration of $5000 \mu \mathrm{g} /$ $\mathrm{ml}$ after 72 hours of exposure. This exceeds the inhibitory rate of cow colostrum lactoferrin, which is $48.66 \%$. Cytotoxicity of goat lactoferrin against the REF cell line at the concentration of $5000 \mu \mathrm{g} / \mathrm{ml}$ after 72 hour exposure was only $19.22 \%$ [38].

Furthermore, the cytotoxicity of goat colostrum peptides was investigated against the rat C6 glioma cell line - the tumor cell death was revealed to be above $70 \%$. Antitumor activity of these peptides is associated with the cationic character of the proteins, the interaction of which with the negatively charged tumor cell membrane destabilizes their membrane. At the same time, the goat colostrum proteins do not harm normal cells because they have a neutral charge [16].

Proteins of fermented goat milk also can be used for the prevention and treatment of oncological diseases. The anticancer effect of goat milk fermented by Lactobacillus plantarum and Lactobacillus paracasei was investigated. In vitro antitumor activity was studied using HeLa cell lines, which were treated with milk hydrolysates at various concentrations (30-240 $\mu \mathrm{g}$ of protein) and incubated at $37{ }^{\circ} \mathrm{C}$ for $4 \mathrm{~h}$. It has been observed that the cell viability decreased with increased concentration of the goat milk hydrolysate.

The antitumor activity may be associated with the presence of enzymes $\beta$-glucuronidase, 
azoreductase and nitroreductase in the intestinal tract, which are capable of converting procarcinogens to carcinogens, along with the bacteria Lactobacillus present in fermented milk, which reduce the concentration of $\beta$-glucuronidase and decrease the conversion of procarcinogens to carcinogens [39].

Therefore, the in vitro studies have shown that goat milk and colostrum proteins are effective in inhibition of tumor cell growth, so they can be potential agents for the treatment of cancer.

\section{Goat colostrum bioactive peptides capable of reducing blood pressure}

A key role in the regulation of blood pressure is played by the angiotensin converting enzyme (ACE), which catalyzes the conversion of angiotensin I to vasoconstrictive angiotensin II. The inhibition of ACE with natural inhibitors, for example goat colostrum peptides, as an alternative to avoid the side effect of synthetic drugs, is a major target in the prevention of hypertension.

Scientists have found that peptides of goat colostrum, such as $\beta$-lactoglobulin, $\beta$-casein and $\kappa$-casein exert significant ACE inhibitory activity, comparable to that of an antihypertensive drug captopril - the $\mathrm{IC}_{50}$ values are $4.45 \mu \mathrm{M}$ and $4.27 \mu \mathrm{M}$, respectively. Therefore the ACE-inhibitory peptides of goat colostrum may be potential candidates as antihypertensive medicines [40]. Among the identified sequences of ACE-inhibitory peptides, eighteen were identical to known bioactive peptides with the ACE-inhibitory activity. The antihypertensive tripeptides valine-prolineproline and isoleucine-proline-proline are especially active [41].
Casein and whey protein fractions of goat colostrum hydrolyzed with subtilisin and trypsin release the ACE inhibitory peptides. The most active $\mathrm{F} 4$ fraction is characterized by $\mathrm{IC}_{50}$ between 9.3 to $5.1 \mathrm{mg} / \mathrm{ml}$. Most of active peptides have a molecular weight below $2 \mathrm{kDa}$, one particularly active dipeptide is very hydrophobic [42]. Consequently, goat colostrum proteins and peptides are able to reduce blood pressure by ACE inhibition.

\section{Anti-atherogenic properties of goat colostrum}

Anti-atherogenic effect is characterized by the prevention of cardiovascular diseases, in particular, atherosclerosis. Lipids, especially the polar ones, and fatty acids of goat colostrum exhibit strong anti-atherogenic activities; they inhibit the platelet aggregation induced by the platelet-activating factor (PAF). This fact highlights the value of goat milk and colostrum in terms of cardioprotection, because PAF is the most important inflammatory mediator involved in the mechanism of atherogenesis [44].

\section{Goat colostrum proteins in the treatment of rheumatoid arthritis}

Rheumatoid arthritis is a chronic inflammatory disease with multiple risk factors associated with chronic soft-tissue inflammation often followed by the bone and cartilage destruction. With rheumatoid arthritis, there is a high risk of osteoporosis and a decrease in bone mass.

Scientists have discovered that the goat colostrum protein $\alpha-\mathrm{S} 2$ casein has an anti-osteoporosis effect on rheumatoid arthritis. $\alpha$-S2 casein is able to repair the collagen structure in the femur trabecular bone [45]. 
The goat milk $\alpha$-S2 casein also has a protective effect on the ileum microstructure and inflammation in rheumatoid arthritis. $\alpha$-S2 casein could repair the ileum microstructure, suppress inflammatory process, and increases the body weight, food intake and albumin level in rats with rheumatoid arthritis [46].

Consequently, the goat colostrum $\alpha-\mathrm{S} 2$ casein may be effective in the treatment of rheumatoid arthritis via suppressing inflammation of the ileum [46] and restoring collagen structure in the femur trabecular bone [45].

\section{Conclusions}

In conclusion, goat colostrum is a unique product containing a complex of biologically active proteins, which have antimicrobial, immunomodulatory, antioxidant, antitumor properties, so the goat colostrum has a wide potential for its application in the treatment of infectious, cardiovascular, oncological and autoimmune diseases, as well as in the strengthening of immunity.

\section{References}

1. Zazharska NM, Samoylenko YuV. Chemical and immunological parameters of goat colostrum and milk depending on lactation period. Visnyk Dnipropetrovskoho derzhavnoho ahrarno-ekonomichnoho universytetu. 2016; 2(40):70-75.

2. Biadała A, Konieczny P. Goat's milk-derived bioactive components - a review. Mljekarstvo. 2018; 68(4):239-53.

3. Abbas HM, Hassan FAM., Abd El-Gawad MAM., Enab AK. Physicochemical characteristics of goat's milk. Life Sci J. 2014; 11(1):307-17.

4. Busol LV, Tsyvirko IL, Pavlichenko OV, Heyda IM. Features and requirements for quality and safety of goat milk. Problemy zooinzheneriyi ta veterynarnoyi medytsyny. 2015; 30(2):274-76.

5. Rashid AA, Yousaf M, Salaryia AM, Ali S. Studies on the nutritional composition of goat (Beetal) co- lostrum and its mature milk. Pak J Biochem Mol Biol. 2012; 45(3):113-16.

6. Sánchez-Macías D, Moreno-Indias I, Castro N, Morales-delaNuez A, Argüello A. From goat colostrum to milk: Physical, chemical, and immune evolution from partum to 90 days postpartum. J Dairy Sci. 2014; 97(1):10-16.

7. Rachman AB, Maheswari RRA, Bachroem MS. Composition and isolation of lactoferrin from colostrum and milk of various goat breeds. Procedia Food Sci. 2015; 3:200-10.

8. Azhar MA, Salim N. Isolation and molecular characterization of local goat milk casein for nutraceutical value. MATEC Web Conf. 2017; 97:01084.

9. Jung TH, Hwang HJ, Yun SS, Lee WG, Kim JW, Ahn JY, Jeon WM, Han KS. Hypoallergenic and physicochemical properties of the A2 $\beta$-casein fraction of goat milk. Korean J Food Sci Anim Resour. 2017; 37(6):940-47.

10. Sanmartín B, Díaz O, Rodríguez-Turienzo L, Cobos $A$. Composition of caprine whey protein concentrates produced by membrane technology after clarification of cheese whey. Small Rum Res. 2012; 105(1-3): 186-92.

11. Bolhova NV. Analysis of milk mixtures based on goat milk. Pratsi TDATU. 2018; 18(1):37-42.

12. Loch JI, Bonarek P, Polit A, Światek S, Czub M, Ludwikowska M, Lewiński K. Conformational variability of goat $\beta$-lactoglobulin: Crystallographic and thermodynamic studies. Int J Biol Macromol. 2015; 72:1283-91.

13. Yang Y, Bu D, Zhao X, Sun P, Wang J, Zhou L. Proteomic analysis of cow, yak, buffalo, goat and camel milk whey proteins: quantitative differential expression patterns. J Proteome Res. 2013; 12(4):1660-67.

14. Yuan YG, An L, Yu B, Song S, Zhou F, Zhang L, Gu Y, $Y u M$, Cheng $Y$. Expression of recombinant human alpha-lactalbumin in the milk of transgenic goats using a hybrid pomoter/enhancer. J Anal Methods Chem. 2014; 2014:281031.

15. Vijayan $S$, Radhakrishnan U, Eldho L, Jayavardhanan $K K$. Isolation and purification of lactoferrin from colostrum of malabari goats. J Exp Biol Agricult Sci. 2017; 5(4):550-55.

16. Medeiros GKVV, Queiroga RCRE, Costa WKA, Gadelha CAA, Lacerda RR, Lacerda JTJG, Pin- 
to LS, Braganhol E, Teixeira FC, Barbosa PPS, Campos MIF, Gonçalves GF, Pessôa HLF, Gadelha TS. Proteomic of goat milk whey and its bacteriostatic and antitumour potential. Int J Biol Macromol. 2018; 113:116-23.

17. Le Parc A, Dallas DC, Duaut S, Leonil J, Martin P, Barile D. Characterization of goat milk lactoferrinNglycans and comparison with the N-glycomes of human and bovine milk. Electrophoresis. 2014; 35(11):1560-70.

18. Lu J, Liu L, Pang X, Zhang S, Jia Z, Ma C, Zhao L, $L v J$. Comparative proteomics of milk fat globule membrane in goat colostrum and mature milk. Food Chem. 2016; 209:10-16.

19. Sharma G, Rout PK, Kaushik R, Singh G. Identification of bioactive peptides in goat milk and their health application. J Adv Dairy Res. 2017; 5(4):1000191.

20. Larsson NG, Wang J, Wilhelmsson H, Oldfors A, Rustin P, Lewandoski M, Barsh GS, Clayton DA. Mitochondrial transcription factor A is necessary for mtDNA maintenance and embryogenesis in mice. Nat Genet. 1998; 18:231-36.

21. Pham CT, Ley TJ. Dipeptidyl peptidase I is required for the processing and activation of granzymes A and B in vivo. Proc Natl Acad Sci USA. 1999; 96(15):8627-32.

22. Lima MJR, Teixeira-Lemos E, Oliveira J, TeixeiraLemos LP, Monteiro AM, Costa JM. Nutritional and health profile of goat products: focus on health benefits of goat milk. Goat Sci. 2018; 10:189-232.

23. Castro N, Gómez-González LA, Earley B, Argüello $A$. Use of clinic refractometer at farm as a tool to estimate the IgG content in goat colostrum. $J$ Appl Anim Res. 2018; 46(1):1505-08.

24. Osman A, Goda HA, Abdel-Hamid M, Badran SM, Otte $J$. Antibacterial peptides generated by Alcalase hydrolysis of goat whey. LWT-Food Sci Technol. 2016; 65:480-86.

25. Almaas H, Eriksen E, Sekse C, Comi I, Flengsrud R, Holm H, Vegarud GE. Antibacterial peptides derived from caprine whey proteins, by digestion with human gastrointestinal juice. Br J Nutr. 2011; 106(6):896-905.

26. Esmaeilpour M, Ehsani MR, Aminlari M, Shekarforoush Sh, Hoseini E. Antimicrobial peptides de- rived from goat's milk whey proteins obtained by enzymatic hydrolysis. J Food Biosci Technol. 2017; 7(1):65-72.

27. Kusumaningtyas E, Widiastuti R, Kusumaningrum HD, Suhartono MT. Antimicrobial and antioxidative activities of peptides from goat milk hydrolyzed with various protease. JITV. 2015; 20(3): 175-83.

28. Yadav AK, Singh J, Yadav SK. Composition, nutritional and therapeutic values of goat milk: A review. Asian J Dairy Food Res. 2016; 35(2):96-102.

29. Lestari $P$. Antibacterial activity of hydrolysate protein from Etawa goat milk hydrolysed by crude extract bromelain IOP Conf Ser Mater Sci Eng. 2019; 509(1):012111.

30. Maga EA, Weimer BC, Murray JD. Dissecting the role of milk components on gut microbiota composition. Gut microbes. 2013; 4(2):136-139.

31. Kumar H, Yadav D, Kumar N, Seth R, Goyal AK. Nutritional and nutraceutical properties of goat milk-a review. Indian J Dairy Sci. 2016; 69:513518.

32. Avaiyarasi ND, Ravindran AD, Venkatesh P, Arul V. In vitro selection, characterization and cytotoxic effect of bacteriocin of Lactobacillus sakei GM3 isolated from goat milk. Food Control. 2016; 69:124-133.

33. Anas M, Zinedine BA, Rizk HA, Eddine HJ, Mebrouk $K$. Screening of autochthonous Lactobacillus species from Algerian raw goats' milk for the production of bacteriocin-like compounds against Staphylococcus aureus. Afr J Biotechnol. 2012; 11(20):4595-4607.

34. Araújo DFS, Guerra GCB., Pintado MME, Sousa YRF, Algieri F, Rodriguez-Nogales A, RodriguezCabezas ME. Intestinal anti-inflammatory effects of goat whey on DNBS-induced colitis in mice. PLoS One. 2017; 12(9): 0185382.

35. de Sousa YRF, da Silva Vasconcelos MA, Costa RG, de Azevedo Filho CA, de Paiva EP, do Egypto $R D C R$. Sialic acid content of goat milk during lactation. Livestock Sci. 2015; 177:175-80.

36. Kalyan S, Meena S, Kapila S, Sowmya K, Kumar $R$. Evaluation of goat milk fat and goat milk casein fraction for anti-hypercholesterolaemic and anti- 
oxidative properties in hypercholesterolaemic rats. Int Dairy J. 2018; 84:23-27.

37. Ahmed AS, El-Bassiony T, Elmalt LM, Ibrahim HR. Identification of potent antioxidant bioactive peptides from goat milk proteins. Food Res Int. 2015; 74:80-88.

38. Bezerra VS, Campos JF, Silva RAD, Porto TS, Lima Filho JLD, Porto ALF. Biotechnological richness of the northeastern semi-arid region: antioxidant activity of casein hydrolysates from Moxotó goat milk (Capra hircus Linnaeus, 1758) obtained by papain action. Food Sci Technol. 2013; 33(3):513-20.

39. Mal G, Singh B, Mane BG, Sharma V, Sharma R, Bhar R, Dhar JB. Milk composition, antioxidant activities and protein profile of Gaddi goat milk. $J$ Food Biochem. 2018; 42(6):e12660.

40. Li Z, Jiang A, Yue T, Wang J, Wang Y, Su J. Purification and identification of five novel antioxidant peptides from goat milk casein hydrolysates. $J$ Dairy Sci. 2013; 96(7):4242-51.

41. De Gobba C, Espejo-Carpio FJ, Skibsted LH, Otte J. Antioxidant peptides from goat milk protein fractions hydrolysed by two commercial proteases. Int Dairy J. 2014; 39(1):28-40.

42. Abbas ZH, Doosh KS, Yaseen NY. Study the effect of purified goat milk lactoferrin on HeLa Cancer Cell line Growth in vitro. Iraqi J Cancer Med Genet. $2015 ; 8(2): 170-75$.

43. Nandhini B, Palaniswamy M. Anticancer effect of goat milk fermented by Lactobacillus plantarum and Lactobacillus paracasei. Int J Pharm Pharm Sci. 2013; 5(3):898-901.

44. Ibrahim HR, Ahmed AS, Miyata T. Novel angiotensin-converting enzyme inhibitory peptides from caseins and whey proteins of goat milk. $J$ Adv Res. 2017; 8(1):63-71.

45. Tagliazucchi D, Shamsia S, Helal A, Conte A. Angiotensin-converting enzyme inhibitory peptides from goats' milk released by in vitro gastro-intestinal digestion. Int Dairy J. 2017; 71:6-16.

46. Espejo-Carpio FJ, De Gobba C, Guadix A, Guadix EM, Otte $J$. Angiotensin I-converting enzyme inhibitory activity of enzymatic hydrolysates of goat milk protein fractions. Int Dairy $J$. 2013; 32(2):175-83.
47. Miglani S, Patyar RR, Patyar S, Reshi MR. Effect of goat milk on hepatotoxicity induced by antitubercular drugs in rats. J Food Drug Anal. 2016; 24(4):716-21.

48. Poutzalis S, Anastasiadou A, Nasopoulou C, Megalemou K, Sioriki E, Zabetakis I. Evaluation of the in vitro anti-atherogenic activities of goat milk and goat dairy products. Dairy Sci Technol. 2016; 96(3):317-27.

49. Fatchiyah F, Setiawan B, Suharjono S, Noor Z. The anti-osteoporosis effects of CSN1S2 protein of goat milk and yoghurt on a complete Freund's adjuvantinduced rheumatoid arthritis model in rats. Biomark Genom Med. 2015; 7(4):139-46.

50. Rohmah RN, Widjajanto E, Fatchiyah F. Protective effect of CSN1S2 protein of goat milk on ileum microstructure and inflammation in rat-CFA-induced rheumatoid arthritis. Asian Pac J. Trop Dis. 2015; 5(7):564-68.

\section{Поліфункціональні властивості білків козиного молозива та їх використання}

К. І. Солошенко, I. В. Лич, І. М. Волошина, Л. В. Шкотова

В огляді наведено склад козиного молозива, антимікробні, імуномоделюючі та антиоксидантні властивості біологічно активних білків молозива кіз, а також розглянуто перспективи їхнього застосовування у медицині. Завдяки наявності комплексу біологічно активних білків, таких як лактоферин, лізоцим, лактопероксидаза, імуноглобуліни, тощо, козине молозиво сприяє підвищенню стійкості організму до інфекційних захворювань, зміцненню імунної системи, має антибактеріальну активність проти широкого спектру мікроорганізмів, володіє антиоксидантною дією, тим самим запобігаючи або затримуючи хронічні захворювання, пов'язані з окислювальним стресом. Крім цього, біоактивні білки молозива кіз демонструють протипухлинну активність, антиатерогенні властивості, здатність знижувати артеріальний тиск та виявляють ефективність у лікуванні ревматоїдного артриту.

Кл юч о в і с л о в а: козине молозиво, білковий комплекс, антимікробна активність, імуномоделюючі влас- 
тивості, антиоксидантний ефект, терапевтичне застосування.

\section{Полифункциональные свойства белков козьего молозива и их использование}

К. И. Солошенко, И. В. Лыч, И. Н. Волошина, Л. В. Шкотова

В обзоре описан состав козьего молозива, антимикробные, иммуномодулирующие и антиоксидантные свойства биологически активных белков молозива коз, а также рассмотрены перспективы их применения в медицине. Благодаря наличию комплекса биологически активных белков, таких как лактоферрин, лизоцим, лактопероксидаза, иммуноглобулины и т.д., козье молозиво способствует повышению устойчивости организма к инфекционным заболеваниям, укрепле- нию иммунной системы, обладает антибактериальной активностью в отношении широкого спектра микроорганизмов, обладает антиоксидантным действием, тем самым предотвращая или задерживая хронические заболевания, связанные с окислительным стрессом. Кроме этого, биоактивные белки молозива коз демонстрируют противоопухолевую активность, антиатерогенные свойства, способность снижать артериальное давление и проявляют эффективность в лечении ревматоидного артрита.

Кл ючевы е сл ов а: козье молозиво, белковый комплекс, антимикробная активность, иммуномодулирующие свойства, антиоксидантный эффект, терапевтическое применение.

Received 15.03.2020 